David A. Jones

University of Warsaw
Hanzhen Liu

Vistula University

http://dx.doi.org/10.18778/8142-287-1.01

\title{
Tensions Along the Western Pacific Rim of East Asia: Obstacles or Opportunities?
}

\begin{abstract}
Tensions have erupted then lingered along the Western Pacific rim, widened across East Asia, expanded into South Asia. They range from the most threatening, the erratic and belligerent behavior of North Korea, to the mystifying posture of China across the East and South China Seas, to the transparent build-up of "flat top" warships by India and Japan, to a myriad of other indicators of conflict. Each of these problems is solvable, some more easily than others. Each requires cooperation among the nations along the Western Pacific, notably China, frequently absent. Each must involve the United States of America. These tensions, each individually and all collectively, may be viewed pessimistically as obstacles; they are better viewed optimistically as one grand opportunity. Emerging is an opportunity for the United States and China to join forces with their allies as partners leading the way toward global peace, a reinvigoration of what was known as the "Peace of 1945" or "Pax Americana" that can become at once a "Pax Serica" ["China Peace"] as well as what could become known as the "Pax Americana Secunda" ["Second American Peace"]. Allies in the region will have to join forces, they have little choice. This paper will address some internal Strengths and Weaknesses alongside some external Opportunities and Threats that befall each of the participants and all of them collectively. It will focus primarily on the opportunities that will burgeon if China and the United States can work together, as they began to do, seriatim, from the middle of 2017 before each country imposed tariffs on the other as a strategy.
\end{abstract}

Keywords: Asia, China, India, Japan, Pax Americana, Pax Americana Secunda, Pax Serica, CEEC, UNCLOS 


\section{Introduction}

Harvard University's Weatherhead Professor, Graham T. Allison, Jr., has inundated the academic media with warnings to the United States over a possible "Thucydides trap" because, in his view, China is a rising power bent on replacing America as a hegemon or existing power globally but in Asia especially (2017a; 2017b; 2017c). According to Allison, what China's President Xi Jinping wants above everything else is "the rejuvenation of the Chinese nation" (Allison \& Goldberg 2017) or, succinctly, to "make China great again" as Donald J. Trump pledged to "make America great again" as a 2016 Presidential candidate. In his Foreign Affairs article, Allison reaches back to Samuel Huntington, much as he did in his book (Allison 2017a, xix):

The United States embodies what Huntington considered Western civilization. And tensions between American and Chinese values, traditions, and philosophies will aggravate the fundamental structural stresses that occur whenever a rising power, such as China, threatens to displace an established power, such as the United States.

The reason such shifts so often lead to conflict is Thucydides' trap, named after the ancient Greek historian [and general] who observed a dangerous dynamic between a rising Athens and ruling Sparta (Allison 2017c).

Some elements of this forecast come from Allison's book, in which he urges America and China to "avoid the Thucydides trap" (Allison 2017a). Very little doubt exists but that they will do so, as Allison acknowledges (xvii), one reason being that neither the United States nor China is an "empire" at heart, and another reason being that China is far from overtaking the United States economically, militarily, or otherwise.

Figure 1 reflects their comparative economic strength and growth, 1960 to 2016, with the United States always ahead in both strength and growth, according to World Bank statistics. As half a century came and went, the United States' economic strength and growth widened in relation to China, dipping only very recently, reflecting the West's Strength, and China's Weakness; facts China must recognize and does recognize quietly, if not publicly. Evidently, China projects its rise militarily and expects a continuation of that rise, in reliance upon the late $19^{\text {th }}$ and early $20^{\text {th }}$ century American naval strategist American Rear Admiral Alfred Thayer Mahan, USN, upon whom both Imperial Germany and Imperial Japan relied to their detriments in World Wars I and II respectively by following Mahan's 
strategy of heavily fortifying home waters (Asada 2006). On the other hand, British Fleet Admiral Sir John Arbuthnot ("Jacky") Fisher, RN, OM, GCB, GCVO, 1 ${ }^{\text {st }}$ Baron Fisher, argued for the use of submarines to defend home ports, and mobile battle cruisers to gain and maintain positions in distant seas (Sumida 2006), the path Britain and the United States have followed in contrast to China's fortification of the South China Seaways, gaining Opportunity for the West, posing Threats to China. Advice to China: American strategists are not correct all of the time, it is a weakness to rely entirely upon Mahan or any of them. Allison cautions that America and China both must acknowledge that war between them is more likely than has been recognized, and that war is avoidable but in their hands to avoid (Allison 2017a, p. xvii). Others have argued that a new "clash of civilizations" is emerging, with a "quad" of nations that includes America, Australia, India, and Japan, spearheading a challenge to China's rising power ambitions, working together and separately to challenge China, to construct a new "clash of civilizations" ("'Quad' of democracies 2017") reminiscent of Huntington's in a different region.

Figure 1. Comparative Economic Strength and Growth, U.S. and China, 1960-2016



Source: World Bank, through Allison 2017a, p. 6.

Allison has presented competing International Monetary Fund data that suggests also that China is surpassing the United States in terms of its rising Gross Domestic Product (GDP) as measured by Purchasing Power Parity (PPP) (Allison 2017a, p. 11), depicted in Figure 2. Note 
that the IMF data includes China's "nominal GDP" that is significantly lower than its PPP. If Chinese consumers become able to buy more goods than American consumers, this should be to America's advantage at least in the foreseeable future, provided that the Chinese buy American or Allied Western (European) goods that American businesses manufacture, preferably doing this manufacturing at home to increase United States GDP, or if abroad, that it is done in factories owned by American companies or individuals such that it becomes part of United States Gross National Product (GNP). That said, both authors made research trips to China for nearly a month in the summers of 2017 and 2018, interviewed Chinese consumers and shopped themselves. Consumer reports corroborate the authors' findings that prices of Chinese-made consumer goods have risen, and quality has fallen. Comparing prices and quality of goods sold in China with similar goods sold in Europe and North America, the Price to Performance Ratio (PPR) is lower in China than in Europe or North America. Chinese consumers tend to purchase American or European products when this option is available to them. This fact is evident at least anecdotally from the authors' observation of Chinese shoppers who tend to frequent American stores or Chinese stores that display and sell American brands across the spectrum of products. It is confirmed by observing automobiles driven by the rising Chinese middle class, frequently Cadillac, Buick, GMC sports utility vehicles (SUVs) and Ford Thunderbirds. It is reinforced by observing what younger Chinese are wearing, American brands, for sure, but also any brand that displays writing or slogans in English, sometimes with an American flag displayed prominently, with this clothing seeming to be newer in 2018 than in 2017. What may be perplexing to Chinese leaders is that America seems to have remained as popular as ever among upwardly mobile Chinese consumers, even more so in 2018 after the tariffs were announced by President Trump compared with 2017, before talk of tariffs.

Political scientists including Allison assume facts not in evidence, predicating forecasts on assumptions that are far from being accurate at the present moment, even further away from being provably sustainable across the foreseeable future. This causes alarm and exacerbates tensions along the Western Pacific rim of Asia and in the West. Many grounds exist to justify a rise in tensions between East and West. Rarely do solid grounds for alarm involve China directly as much as they tend to involve 
the United States, its European Allies and the Russian Federation. To be sure, China should be able to perform better in the rising role that it seems to be courting, that of an international peace keeper. In this role, China and the United States should be capable of joint policing around the world, most notably in Asia, making Chinese displacement of American or Western influence unnecessary. In this role, China and the European Community, China and its neighbors in Asia including India, Japan, and South Korea plus the ASEAN block, all should be capable of joining forces to maintain a prosperous and tranquil community of nations globally. The highest risk of this paradigm becoming derailed is the potential of financial default along OBOR, including but not limited to Eurasian nations defaulting on their obligations to service Chinese loans, to repay debt to China, and their implicit obligation to maintain friendly ties, both to China and to each other as co-participants in a common venture. This is a "bubble," partially economic, the rest political. If one seam in this figurative garment bursts, potentially the rest will become damaged beyond repair, leading to a global recession, akin to the stock market implosion of 29 October 1929.

Figure 2. Chinese and American Gross Domestic Product (GDP) Growth Based on Purchasing Power Parity, 1980-2021 (2017-2021 is estimated)
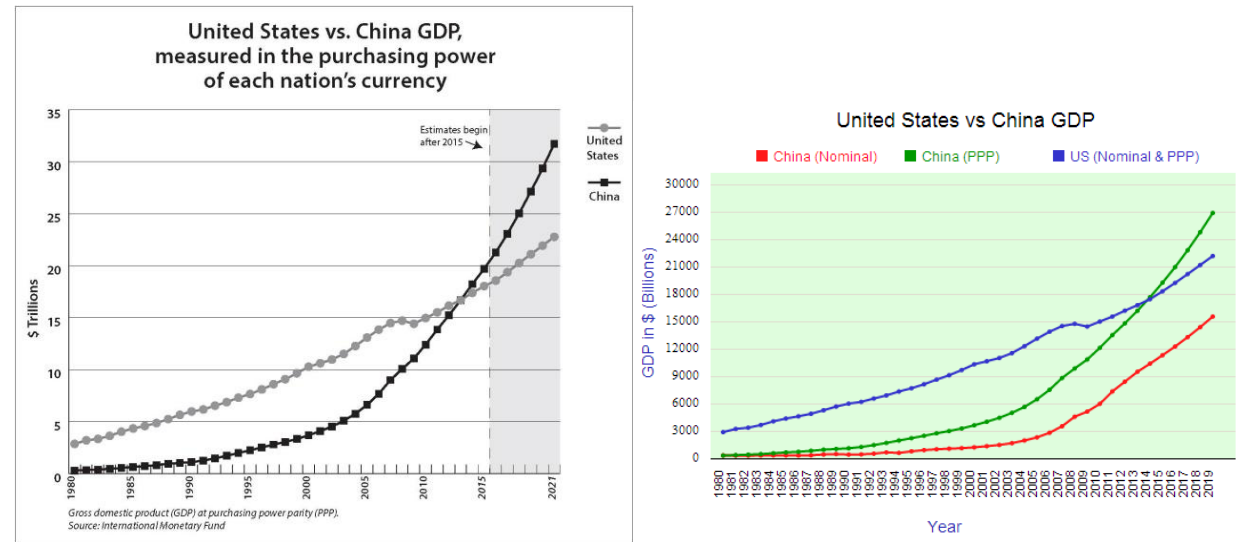

Source: [Left] International Monetary Fund, through Allison, G. 2017a, p. 11. [Right] Statistics Times 2015.

If China's PPP is rising to the point where it is surpassing the PPP of the United States, this does not mean at all that a "Thucydides Trap" awaits the United States. Just as easily, probably more so, it can be an 
indicator of a rising Chinese middle class that will become a threat to the survival of the Chinese Communist Party, as people of China strive to "make China great again" on their own without party leadership. Accordingly, the headache for President Xi Jinping is less on the international front than on the domestic front, and the rise of unspoken domestic tensions inside China is affecting the Chinese government's ability and willingness to act proactively to subdue international tensions. This is a reason why President $\mathrm{Xi}$ has displayed reluctance to intervene forcefully or rapidly in conflicts with India on China's western border or to intervene forcefully or rapidly against the "Democratic" People's Republic of Korea (DPRK) on China's northeastern border. In each example, Chinese leaders are afraid to unleash thousands of troops because these troops could turn inward against China's current leadership. Stated differently, Chinese leaders fear internal tensions more than they fear external tensions (Annual Report 2016, pp. 48-49). What does this signify in an international context? It means that if the United States should attack North Korea, China will do absolutely nothing about it for multiple reasons: deployment of many divisions of the People's Liberation Army (PLA) is to mobilize an armed component of the Chinese citizenry, dangerous in itself to ongoing party control of governance, and any major conflict with the United States or the West generally will stunt China's PPP growth, even more dangerous to sustainable continuation of party control of governance. That would become an example of China's internal Weakness.

At least three theaters of potential conflict exist across Asia: the Korean Peninsula, Kashmir and South Asia generally, and the South China Sea region. Each may be considered to be a dynamite stick waiting to be ignited, but the Korean Peninsula is the area with the most external Threat because the DPRK is playing with fire in the form of nuclear testing and missile launching. If those two military assets are commingled as matters stand at the moment, the Korean Peninsula and Japan await possible devastation, the former more than the latter. Much of this problem arose, then accelerated almost out of control, because Western leaders, particularly liberals, opted to stand by idly as three generations of the dictatorial family Kim constructed an albatross from a weasel, instead of striking North Korea down as they should have done long ago and as inevitably they will have to do very soon, using the massive firepower the West possesses before North Korea possesses the same. 


\section{One Country, Two Belts}

Chinese leaders are marketing China's "One Belt, One Road" initiative across up to 65 countries from Eurasia to Europe and across the Indian Ocean to Africa (Phillips 2017). Less attention is directed toward China's domestic "rust belt," an area of Northeast China situated close to its border with North Korea that displays high unemployment, and antiquated infrastructure. Here, workers who eek out their livelihood trading goods to buyers in North Korea admit United Nations sanctions are appropriate, but they report their cottage industries run the risk of closure in the face of the same sanctions (Martin \& Chen 2017). The impact on China's domestic stability appears to be an important reason why President $\mathrm{Xi}$ Jinping is reluctant to enforce sanctions against North Korea more robustly, according to Lyu Chao at the Liaoning Academy of Social Sciences in Shenyang:

A loss in border trade could potentially destabilize China's strategic plan to revive the industrial economy in the northeast, a plan the central government won't allow to be disturbed by international affairs. ... Maintaining stability in northeast China is very important to the government (Martin \& Chen 2017).

So whilst China is exporting what it portrays to be an outward Foreign Direct Investment (OFDI) initiative which it labels "One Belt, One Road" or "OBOR", an initiative that will bring prosperity abroad, the same China is trying desperately to avoid political instability at home by maintaining economic growth across its other "belt", sometimes termed China's "rust belt" in its Northeastern region. Said differently, although China's OBOR appears to be an economic boost to recipient nations that are China's neighbors across Eurasia and Central and Eastern European Countries (CEEC), this prosperity may come at a cost to China's domestic economic growth. It is unlikely to stem the rise of China's educated middle class, and so equally unlikely to delay or stop desire by Chinese consumers to purchase goods from the West. It may frustrate the ability of China's under-educated population to become competitively educated and thereby join China's rising middle class in the near future. An inevitable consequence of this economic disparity could be a domestic "clash of civilizations" by education level, by region (urban contrasted with rural), or by occupation (manager vs. worker). An example of this dichotomy is the presence of at least one, frequently multiple, picture(s) of former Chinese 
Chairman Mao Zedong as a centerpiece in poorer Chinese homes, with such an icon being absent almost entirely from the homes of $21^{\text {st }}$ century educated Chinese.

If China pursues its OBOR initiative all the way to the European Community, building a planned deep water cargo port at Piraeus near Athens, Greece, as the senior author of this article recommended in 2015 (Jones 2015b) and that China announced in 2017 it plans to turn into reality, as The New York Times reported (Horowitz \& Alderman 2017), China's investment in Greece stands to alter European Community architecture by moving its "core" to the East, raising the affluence of Europe's Eastern periphery significantly. Over numerous decades, CEEC have been growing poorer relatively as many East Asian and Western European countries have improved their prosperity, because of a lower increase in manufacturing as a percentage of their GNP (Tanoos 2014, p. 453), as Figure 3 below reflects. Arguably, this comes at the expense of the CEEC block:

The hierarchical relationship at global level with a 'Core' consisting of the US, the EU and Japan (the Triad) and a Periphery consisting of so-called 'developing' countries is reproduced within the 27 member states [currently 28] of the EU. The Core consists here of the most powerful countries among which Germany and France, but also the UK, Italy and the former Benelux (the Netherlands, Belgium and Luxembourg). The Periphery is subjected to decisions made by this hegemonic Core and mainly consists of countries lying to the south and east of the EU, not forgetting Ireland to the West. At the more limited level of the euro zone ( 16 countries), the same distinction resulted in the acronym PIGS (Portugal, Ireland, Greece and Spain), that has prompted outrageously racist puns (Toussaint 2011).

Arguably, Chinese FDI into the CEEC bloc will add to the enormous economic rise of the CEEC region. Consider Figure 3 below, and its relative implications.

With the projected exit of the United Kingdom from the European Union (EU), known as "Brexit", the Western periphery of Europe will become less prosperous, ceteris paribus. With the opening of a deep water cargo port at Piraeus as the gateway to Europe for goods produced in Asia, the Eastern periphery of Europe will become more prosperous. This fact should be evident without figuring into the equation another reality, that a deep water cargo port at Piraeus will divert many billions of euro annually away from existing deep water ports in Western Europe such as Amsterdam, Hamburg and Rotterdam (not to mention Gibraltar that may exit the EU with Brexit), reducing some Western European prosperity, in that process leveling the playing field between East and West Europe considerably. 
Figure 3. Economic Growth Attributed to Industry, by country and by region

\begin{tabular}{|l|c|c|l|l|c|c|c|}
\hline $\begin{array}{l}\text { Eastern } \\
\text { Europe }\end{array}$ & $\begin{array}{c}\text { Change } \\
\text { since } \\
\text { 1991 or } \\
\text { earliest } \\
\text { entry }\end{array}$ & $\begin{array}{c}\text { Manu- } \\
\text { facturing } \\
\text { value } \\
\text { added (\% } \\
\text { of GDP, } \\
\text { 2010) }\end{array}$ & Calculator & East Asia & $\begin{array}{c}\text { Change } \\
\text { since } \\
\text { 1991 or } \\
\text { earliest } \\
\text { entry }\end{array}$ & $\begin{array}{c}\text { Manu- } \\
\text { facturing } \\
\text { value } \\
\text { added (\% } \\
\text { of GDP } \\
\text { 2010) }\end{array}$ & Calculator \\
\hline Albania & 9.2085 & 16 & 1.4734 & China & 12.0430 & 30 & 3.6129 \\
\hline Belarus & 3.1548 & 30 & 0.9464 & $\begin{array}{l}\text { Indone- } \\
\text { sia }\end{array}$ & 4.1927 & 25 & 1.0482 \\
\hline $\begin{array}{l}\text { Bosnia / } \\
\text { Herzego- } \\
\text { vina }\end{array}$ & 6.1560 & 14 & 0.8618 & $\begin{array}{l}\text { South } \\
\text { Korea }\end{array}$ & 3.1985 & 30 & 0.9596 \\
\hline Bulgaria & 3.2870 & 16 & 0.5259 & Malaysia & 4.2559 & 25 & 1.0640 \\
\hline Croatia & 4.3323 & 16 & 0.6932 & $\begin{array}{l}\text { Philip- } \\
\text { pines }\end{array}$ & 3.5768 & 21 & 0.7511 \\
\hline $\begin{array}{l}\text { Czech } \\
\text { Republic }\end{array}$ & 6.0670 & 24 & 1.4561 & $\begin{array}{l}\text { Singa- } \\
\text { pore }\end{array}$ & 4.4327 & 22 & 0.9752 \\
\hline Estonia & 3.9396 & 17 & 0.6697 & Thailand & 2.6789 & 36 & 0.9644 \\
\hline Greece & 3.3551 & N/A & N/A & Vietnam & 11.5813 & 20 & 2.3163 \\
\hline Hungary & 4.5172 & 23 & 1.0390 & & & & \\
\hline Latvia & 4.1356 & 12 & 0.4963 & & & & \\
\hline $\begin{array}{l}\text { Lithua- } \\
\text { nia }\end{array}$ & 4.4404 & 16 & 0.7105 & & & & \\
\hline Poland & 6.3768 & 18 & 1.1478 & & & & \\
\hline Romania & 5.3894 & 15 & 0.8084 & & & & \\
\hline Russia & 2.6073 & 15 & 0.3911 & & & & \\
\hline Serbia & 2.6564 & 16 & 0.4250 & & & & \\
\hline Slovakia & 8.3361 & 21 & 1.7506 & & & & \\
\hline Slovenia & 3.5453 & 21 & 0.7445 & & & & \\
\hline Ukraine & 1.6308 & 18 & 0.2935 & & & & \\
\hline Average & 4.62 & $\mathbf{1 8 . 1 2}$ & $\mathbf{0 . 8 4 9}$ & Average & 5.74 & \\
\hline
\end{tabular}

Source: World Bank Group through Tanoos 2014, pp. 444-456, 453, Table 9.

This condition will "move Europe East" by making the "core" move more Eastward, then with that process the periphery will follow also. Chinese officials portray OBOR as a new model of "global governance" involving innovative projection of Chinese influence beyond its borders (He 2017)

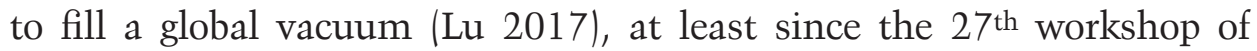


China's Political Bureau held on 12 October 2015 (Sanwal 2016). In this respect, clearly OBOR functions as an internal Strength to China, as an external Opportunity for host nations. It may be regarded as an external Threat by some Western European competitor nations, particularly in the light of profit declines for Chinese Overseas Shipping Company (COSCO) ports in 2017 ("Cosco Shipping Ports' Profit Down as Volumes Rise" 2017) followed by an even steeper decline in COSCO profit margins generally in 2018 (Keefe 2018).

Both authors of this article have criticized aspects of OBOR recently, although both support OBOR in principle: (1) some or even many of the Eurasian countries that once were provinces of the Soviet Union may be unable or unwilling to service OBOR loans, defaulting on the same and harming the Chinese people's sovereign wealth; (2) OBOR already appears to have agitated the Russian Federation in its self-image as the rightful successor to the former Soviet Union; (3) OBOR already appears to have annoyed Turkey, which aims to enlarge its domain with China's Western Xinjiang Province and much of the Moslem territory in between, considering itself to be the rightful successor to the former Ottoman Empire; (4) politicians and some scholars from Western Europe challenge OBOR at least rhetorically ("China's Project of the Century" 2017), seeming to resent China's decision to pour much of its investment in Europe into the CEEC region in the beginning (Jones \& Liu 2017). Perhaps Western European resentment is on account of its wish, actually or subliminally, to keep Eastern Europe backwards, as Toussaint contends (2011). At least arguably, more good than harm will come from the OBOR initiative, largely because of the OBOR "dragon head" port at Piraeus, Greece (Horowitz \& Alderman, 2017). Once that port becomes operational, goods unloaded from ships will then be distributed across Europe by highway or railway, either way passing through Poland and spawning new industries in Poland and elsewhere across CEEC, rapidly increasing the prosperity of CEEC nations generally, particularly Poland and other flexible and forward searching countries.

\section{From Weasel to Albatross to Extinction}

Global attention is focused on North Korea because of the weapons of mass destruction the regime that controls that country has threatened to use against the United States mainland, against American assets abroad, and against Allies of the United States, including not only South Korea 
but also Japan, and possibly others. Almost no attention is focused on the North Korean threat to China, its next-door neighbor, notwithstanding the obvious fact and nearly unspoken reality that a nuclear-armed Korean Peninsula would pose a massive threat to China including both the Chinese Mainland and Taiwan. Western recalcitrance to "annihilate" North Korea has been grounded for decades on an excuse: that China would enter the conflict. It would be very unlikely to do so, because Chinese interests would be strengthened not weakened by the demise of North Korea, long an economic drain on the Chinese population, provided that hordes of North Koreans will not stampede across the Yalu River into China without consideration of their accommodation.

It has been said that "[ $\mathrm{t}]$ he only way forward to avert a full-blown North Korean nuclear arsenal is by radically modifying the constants and variables that are holding the current trajectory in place" (Soesanto 2017). Exactly correct, but what are the "constants," what are the "variables," and how can either or both be "modified" with an ending satisfactory to everyone else? Only one constant is relevant here: North Korea under the Kim administration is a grave danger. Another constant, that China is its protector, is vanishing fast. Variables germane to this equation are led by the fluctuating gravity of North Korea's dangerousness. Recently, that gravity clearly has escalated. Some perceive Kim's professed desire for negotiation to be another variable. It is a constant: Kim is a dictator unaccustomed to conversation over anything. What game plan is viable? Soesanto has proposed the following as alternative courses of action:

Currently there are four strategic approaches vying for public attention: (1) A preventive war or decapitating strike, (2) strengthening deterrence and implementing tougher sanctions with the aim of achieving diplomatic progress vis-à-vis Pyongyang, (3) negotiating a grand bargain between the United States and Beijing on the denuclearization and future of the peninsula, and (4) simply doing nothing, e.g. embracing the reality of a nuclear-tipped North Korean missile arsenal.

All four approaches have one thing in common: They have a grain of strategic logic embedded in them, but make for terrible policy advice $(2017$, p. 1).

Do they, really? Does each alternative "have a grain of strategic logic," do they all "make for terrible policy advice"? Strengthening deterrence will not achieve greater diplomatic progress, nor will implementation of tougher sanctions. Dictators of Kim's ilk will not negotiate (Bershidsky 2017), and sanctions seldom work anyway. China's foreign ministry raised the question: "After so many rounds and vicious cycles, do [the 
United States and its allies] feel they are nearer to peaceful settlement of the issue?" (Soesanto, p. 1). President Donald J. Trump declared in September 2017 that "talking is not the answer" (2). If the two most important parties to past and prospective diplomatic talks agree that more conversation will be fruitless, then discussion is not a viable option. Former United States secretary of state Dr. Henry A. Kissinger proposed a "grand bargain" with China (2), but this presupposes that China controls North Korea when, clearly, it wields no control and its eroding influence is waning rapidly. Rejecting preemptive air strikes, Soesanto has proposed to "let deterrence fail":

Overall the strategy of letting deterrence fail would be aimed at: (1) building strong public support inside South Korea for U.S. military strikes against the North, and (2) rallying the international community behind a last goodwill effort to make Pyongyang comply with its obligations to denuclearize (Ibid.).

It is the Western Alliance led by the United States that has the responsibility to protect Japan as an Ally together with the United States homeland itself and other Allies. "Public support inside South Korea" is not required, and far too many "goodwill" efforts have been proffered and failed. Probably the only option, clearly the best option, is a preemptive strike. As United States Senator Lindsey Graham has said, "if there's going to be a war to stop [DPRK], it will be over there. If thousands die, they're going to die over there. They're not going to die here" (Soesanto 2017 , p. 3). That is entirely correct, but only if North Korea is annihilated before its missile capabilities increase. Time is running out very swiftly. As Soesanto reminds us: "For far too long has Washington carried a big stick without ever wielding it, and for far too long has tough talk been cheap on the peninsula. It is time to change both" (Ibid.). Correct, but with military attacks. President Trump has displayed the "killer instinct" in his business dealings. It is high time for him to display the same in the United States' international relations.

If military strikes on North Korea are the best option, even if not the only option as seems to be the case at present, what should be the targets? What might be termed the Soesanto Plan is:

U.S. Department of Defense ought to compile a list of thirty high-value military and political targets inside North Korea. For every missile Pyongyang puts into the air, the U.S. military will strike two listed targets; and for every nuclear test conducted, a North Korean city will be indiscriminately bombed (Ibid.). 
At least two glaring flaws can be seen in this option. Divulging target assets in advance of bombing would pose unreasonably high risk to pilots and presumably stealthy aircraft. To bomb cities indiscriminately would violate the law of warfare.

It is correct that any operation against North Korea should not be undertaken solely by the United States, but by an alliance of interested stakeholders within or outside of the Pacific rim neighborhood. Strikes should not be directed seriatim, but as part of a single massive strategy to annihilate every military capability of North Korea on its territory and everywhere else such as on or under the ocean. The Alliance cannot target civilians indiscriminately, although collateral damage with incidental casualties can be expected to be high. Striking aircraft should be deployed from aircraft carriers Northeast of North Korea or from far away, and should commence endless striking ("carpet bombing") along the border with South Korea and northward thereafter in an effort to minimize retaliation against South Korea. American personnel stationed in South Korea will be in harm's way, they should not be withdrawn. If "boots on the ground" are required, they should be Asian troops not American. Ordnance utilized in this operation cannot all be from manned aircraft. Drones and missiles from littoral surface warships and submarines, possibly also from space, should be considered as well. Although any attack on North Korea should not deliberately attack civilians, this operation cannot deliberately avoid the civilian population, either. It must be remembered that, just as the Holocaust in Germany, 1933 to 1945, was not limited to dozens of clowns from Munich, the Holocaust North Korea threatens to its neighbors and beyond is caused by the North Korean population having failed to rein in the Kim family years back. The German population paid a steep price for electing Adolf Hitler as their chancellor, the North Korean population will pay a steep price for the Kim Family's antics. Chinese, Japanese, and South Korean neighbors as well as Americans beyond the seas should not have to absorb this cost, so their governments must meet their obligations to neutralize the North Korean threat immediately.

Following President Trump's address before the United Nations General Assembly on 19 September 2016, the North Korean ambassador to the United Nations announced that his country possesses the right to "shoot down" United States warplanes flying outside of its sovereign air space, because it contends President Trump's speech amounted to a "declaration of war" on North Korea, justifying it in "shooting down" Amer- 
ican warplanes even if flying outside of its sovereign airspace (Gladstone \& Sanger 2017). Only the United States Congress is empowered under the United States Constitution to declare war on any nation. In his aggressive speech, President Trump referred to North Korean dictator Kim Jong-Un as "Rocket Man" (Blake 2017). By claiming a right to shoot down American warplanes flying over or near the Korean Peninsula outside of North Korea's airspace, apparently North Korea is asserting its sovereignty over all of the Korean Peninsula, much as China contends the South China Sea is its sovereign area. An important difference is axiomatic between China and the DPRK, however. In asserting its own historical "sovereignty" over the South China Sea region, China is willing to permit all nations to continue to traverse that maritime vicinity. What the DPRK will permit remains ambiguous.

\section{4. "Dragon-Elephant" Tensions in Kashmir: China's "New Silk Road"}

Kashmir is a territory high in the Himalayas mountain range that is located between China and what was once greater India, on the one hand, and that is located between India and Pakistan at the present time, on the other hand. Much of Kashmir is divided between India and Pakistan, and China aims to extend its "New Silk Road" across Pakistani Kashmir in order to reach Pakistan's port of Gwadar on the Arabian Sea that is about 500 kilometers across the Indian Ocean from Dubai in the Middle East, much to the chagrin and consternation of India, Pakistan's nemesis, harboring a fear that Gwadar could eventually become a Chinese naval base on the Indian Ocean (Mangi 2016). At the first meeting of the "Raisina Dialogue," India's Foreign Secretary Subrahmanyam Jaishankar asserted that "connectivity" has "emerged as a theater of present day geopolitics", referring to the OBOR initiative without naming it or China (Mangi 2016). Western journalists have explained OBOR as being China's unspoken effort to deal with emerging industrial overcapacity in its steel and manufacturing sectors, requiring it to increase its exports geometrically, labeling this as being a "New Great Game" with the "Silk Road" really functioning as "the road to a new empire" (Clover \& Hornby 2015).

Next door to Kashmir is Xinjiang, China's largely Muslim northwest province, beneath which crisscross pipelines that have been built already 
or that are planned to be constructed, soon to be joined by overland highways and railways that will form China's "New Silk Road" network:

Through pipeline networks Xin Jiang connects China with the oil of Kazakhstan and the natural gas of Turkmenistan. Moreover the Russo-Chinese Altai pipeline will cross Xin Jiang if ever constructed. The Altai and the Power of Siberia pipelines are two natural gas pipelines that China and Russia agreed to build in the summer of 2014. The New Silk Roads promoted by China will also have to cross Xin Jiang. The New Silk Roads are a network of railways, highways and ports, which will bring to China resources from around the globe, and which will allow China to export her products to the rest of the world much faster (Alhadeff 2015).

As a new network of overland highways and railways, together with maritime seaways, China's "new" Silk Road and Silk Route will join its myriad of pipelines, both underground and surface, that traverse its Western frontier. The motives of the "One Belt, One Road" initiative are in dispute, much as these corridors aim to pass through Kashmir, a disputed territory claimed by both India and Pakistan as well as by China itself. According to Yale Global, "The West views this as a Chinese bilateral project being touted a multilateral venture," noting that Jörg Wuttke, outgoing president of the EU Chamber of Commerce in China, contended that the OBOR initiative has been "hijacked by Chinese companies, which have used it as an excuse to evade capital controls, smuggling money out of the country by disguising it as international investments and partnerships ("Hidden Motives" 2017). If true, this means OBOR is simply a gargantuan form of corruption by money laundering within the administration of President Xi Jinping, contrary to his hallmark stance of investigating then prosecuting Chinese corruption, another example of tensions, this time internal. Half a decade ago Chinese officials were accusing each other of "round tripping" with Chinese foreign "investments" by purporting to return those investments to China when in reality what they were repatriating were profits generated from overseas investments, the aim being to avoid legitimate taxation on those profits by laundering their status as profits, making profits seem to be investments recalled then repatriated tax free (Jones 2013). Corruption takes many forms, with FDI having the potential to become a national headache, in this context China as a nation funding other countries across a long distance that is far from the Chinese homeland. Many of those countries, distant from China, have economies that are tottering, face their own corruption challenges domestically, are under immense pressure from Russian Federation officials, both overtly and covertly to 
remain distant from China, and quite frankly lack any visible means of servicing, much less repaying, new debt to China or any other lender. In this respect, OBOR debt may cause concern to European and other powers, much as Cuban debt in 1903 provoked the United States Congress to include the "Platt Amendment" (1903) in the Treaty Between the United States and the Republic of Cuba, forbidding Cuba from contracting large debt with foreign countries, particularly European lenders, fearing those lenders might occupy Cuba in the event of its default on debt to them, inviting European creditors to violate the independence of Cuba and the principles of the Monroe Doctrine (1823).

Figure 4. Overland and Maritime "One Belt, One Road" Connections

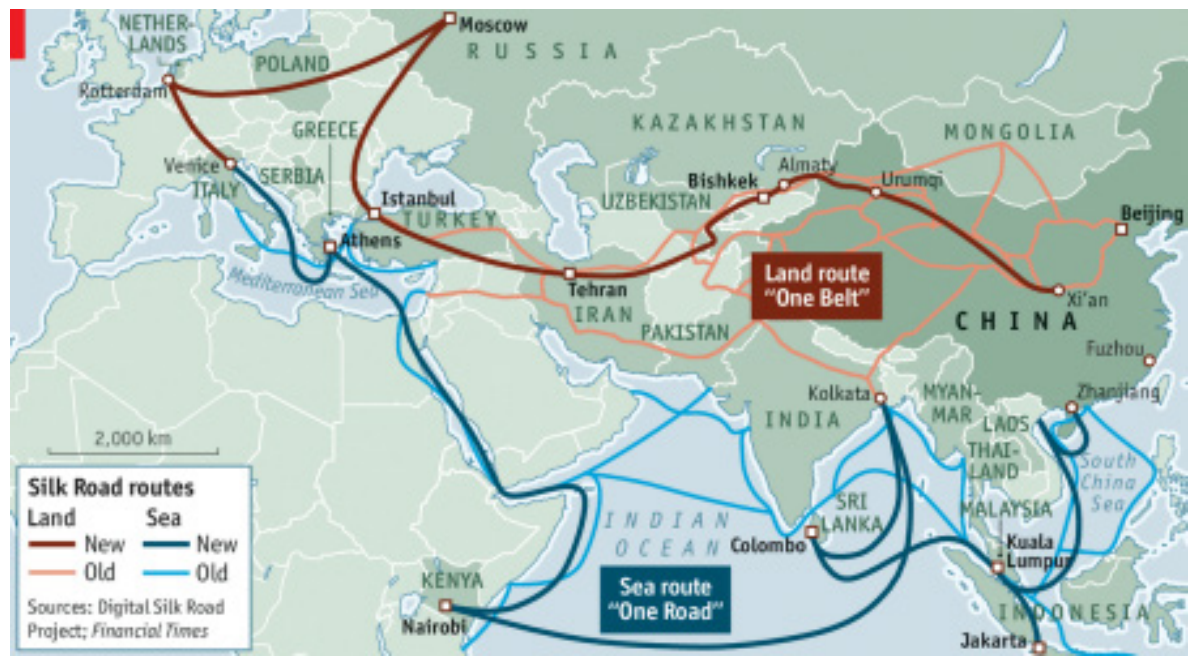

Source: "The Hidden Motives of the Chinese Silk Road" 2017.

According to Andrew Small at the German Marshall Fund, author of The China-Pakistan Axis: Asia's New Geopolitics, "[t]he China-Pakistan corridor is the flagship for China's Belt and Road initiative, essentially the only fully-developed section of the entire scheme, and hence an important test case for Xi Jinping's ambitious plans" (Mangi 2016). Be that as it may, China is endeavoring to "dominate sunshine industries" such as highspeed rail lines planned to operate across China's "OBOR" and elsewhere ("China sets its sights" 2017). Leading the way into "new technologies" is fabulous. Tensions increase across Asia and the world if China's "OBOR" or any of its FDI initiatives precipitate friction with states that neighbor China or Europe or each other along the "New" Silk Road across Eurasia 
or the "New" Maritime Silk Route to Africa. Chinese officials deny vehemently that OBOR is a pretext for Chinese military expansion abroad:

OBOR cooperation does not carry the military attempt and geographical strategy. China neither seeks the dominance of the affair in the region, nor the sphere influence, nor the intervention of internal affair to other states (Xin 2017a).

If true, and it is very difficult to document, OBOR is an example of China's global philanthropy. That posture is difficult for the West to believe, also, much as President Ronald Reagan's promise to Soviet Union General Secretary Mikhail Gorbachev that United States Strategic Defense Initiative (SDI or "Star Wars") was either entirely defensive or to be shared with other countries including the Soviet Union, which the Soviets rejected out of hand (Savranskaya \& Blanton 2006). Presumably, Reagan's offer was genuine, just as the Chinese OBOR initiative may be entirely philanthropic. In some Western mindsets, an inference arises that OBOR is or will become an avenue for Westerly expansion of China's military; but that costs money, and China has not earmarked any part of its military budget for this purpose, and its ministry of defense has denied categorically that invisible military expenses have been authorized (Xin 2017b).

\section{Sovereignty of the Oceans? Does "Serica" Rule the Waves?}

International law clarifies that open oceanic areas belong to the international community to use, to traverse without restriction. In question is whether, a given maritime space or land mass emerging therefrom is open ocean or part of an abutting nation's sovereign territory to regulate, known as "territorial waters" or a "territorial sea" as prescribed by the 1982 United Nations Convention on the Law of the Sea (UNCLOS or "Law of the Sea Convention"). Thereunder, the territorial waters of any given state extend no more than 12 nautical miles (13.8 miles, $22.2 \mathrm{~km})$ from the mean low water mark, called the "baseline", of each coastal state as recognized by the United Nations and by other states. Across a bay, this baseline can be no more than double the primary territorial waters rule, or no more than 24 nautical miles ( 28 miles, $44 \mathrm{~km}$ ) long. Each sovereign state exercises jurisdiction over its territorial waters, except that foreign ships may sail through territorial waterways on "innocent passage" and sail through straits 
on "transit passage," with the sovereign state allowed to regulate shipping lanes in the latter. Landward of a baseline, including lakes and rivers, a sovereign state may regulate completely, "innocent passage" is not allowed generally. An exception pertains to "archipelagos" such as waters inside of outermost islands in the case of Indonesia and the Philippines, considered to be internal waters, although innocent passage is allowed. Foreign ships are permitted to exercise "Freedom of Navigation" or "FON" across territorial waterways pursuant to "customary" international law, recently codified as article 87(1)a of the 1982 United Nations Convention on the Law of the Sea (UNCLOS), signed as well as ratified by 162 nations including China, signed but not yet ratified by the United States. When all is said and done, however, the "politics" of the law of the sea remain much as Cheever witnessed them 35 years ago in the formative stages of UNCLOS, rather fragile: "Nowhere is the indissoluble relationship between politics and law demonstrated more cogently than in the law of the sea. This symbiosis is illustrated by the birth of the UN Convention on the Law of the Sea, its growth at the Third UN Conference on the Law of the Sea (UNCLOS III) and by its widely predicted demise" (Cheever, 1984, 247).

Having signed the UNCLOS, China has not strictly obeyed it, to say the least, and skirted it at almost every opportunity within the South China Sea area particularly, also at times and in places across the East China Sea region. It defies continuously the unanimous ruling by the United Nations Permanent Court of Arbitration in The Philippines vs. China, decided on July 12, 2016, holding that China has "no historical rights" based on the "nine-dash line" map it advanced as authority for its claim to sovereignty across much of the South China Sea region. No appeal is permitted under prevailing international laws. By some appearances, to say the least, China is acting as a maritime hegemon. Does "Serica" rule the waves, a sequel to $19^{\text {th }}$ century "Britannia"?

Many factors evidence the West losing the "battle" over the South China Sea as China continues to fortify its "nine dash line" that it contends demarks its historical "sovereignty" over that area (Bray 2017). More than other elements of this equation, the fact that neither China's neighbors nor the United States nor other global maritime nations seem willing to stand up to China's increasingly belligerent posture, and the North Korean missile "testing" across the Yellow Sea is a convenient distraction to mask Chinese aggression (Mollman 2017). In his speech to the United States Congress delivered on January 18, 1918, President (Thomas) Woodrow Wilson articulated "Fourteen Points" he deemed essential to 
global peace in the tottering aftermath of World War I, several of which related to maritime rights and obligations.

In Point Two, Wilson asserted nations must enjoy an "Absolute freedom of navigation upon the seas, outside territorial waters, alike in peace and in war, except as the seas may be closed in whole or in part by international action for the enforcement of international covenants" (Wilson 1918). This is directly applicable to the South China Sea in at least two respects: (1) seafaring routes across the South China Sea or any maritime area that are outside of territorial waters convey "absolute freedom of navigation," and if this covenant needs to be enforced, the international community can close the region wholly or partially. In Point Three, Wilson tied any country's entitlement to trade protection to its behavior on the high seas, arguing "The removal, so far as possible, of all economic barriers and the establishment of an equality of trade conditions among all the nations consenting to the peace and associating themselves for its maintenance," sending a clear signal that countries enjoy trade protection by meeting a two-pronged test: (a) "consenting to the peace" and also "associating themselves for its maintenance." If China fails either prong or both, trade protections could be abated. Senator Henry Cabot Lodge's "Fourteen Reservations" are interesting and applicable hereto as well, Reservation Six especially: "The United States reserves the right to take either side if China and Japan start a war against each other." Each of these points or reservations is as pertinent today as it was a century past. Unless tensions in the South China Sea region are abated soon, trade protections will have to be reconsidered, unless they fall between the cracks.

\section{Strengths and Weaknesses, Opportunities and Threats}

Internal Strengths. China's internal Strengths are many, undoubtedly led by its prowess in the manufacture and/or the assembly of goods in high volume that has rendered it "factory to the world" during the $21^{\text {st }}$ century. That status continues, but stands to diminish progressively unless the trade war with the United States over tariffs can be ended soon. Additional Strengths include China's GNP growth, slowing recently; its burgeoning middle class and the proclivity of Bourgeois Chinese to purchase luxury goods from abroad. Much of this is dependent upon continuity of international trade with the West, meaning Europe and North America. 
Internal Weaknesses. Chinese fortification of the South China Sea region reflects China's internal Weakness in following Alfred Thayer Mahan's discredited theory of arming brown waterways near to a nation's homeland (Asada 2006), creating an external opportunity for adversarial navies to traverse blue waterways to demolish the batteries unrealistically believed to be invincible by the country that constructed them, as Imperial Germany and Imperial Japan proved in the 20th century (Sumida 2006). "Serica" does not rule the waves, it may never do so, or if it does sometime that time is longer than a century away. That China seems willing to risk warfare with its neighbors to the South and West over artificial islands constructed across international waterways in violation of international laws is a gargantuan Weakness.

External Opportunities. OBOR is an external opportunity for host countries across Eurasia and CEEC, particularly the latter that will benefit from Chinese FDI that, in turn, should move the center of Europe eastward. As Europe moves Eastward economically, probably to be followed by moving Eastward politically, this should result in an external Opportunity for China in the form of greater and closer trade, not to mention China's inching out the Russian Federation for influence across Eurasia. Primus inter pares is the deep water cargo port the Chinese Overseas Shipping Company (COSCO) is enlarging at Piraeus, Greece, because this alone will divert from Western Europe to CEEC over USD One Trillion annually in goods arriving in Europe from Asia. Almost certainly, as the "dragon's head" of OBOR (Horowitz \& Alderman 2017) control of the port at Piraeus is a huge and a sustainable external Opportunity for China's rising global imagery. It is unclear at the present time, and likely to remain unclear for longer than a decade, whether OBOR will become an internal Strength or an internal Weakness to China's domestic economy itself, depending upon whether host countries service debt and grant to China the largesse it seems to expect as it endeavors to project a new "global governance" upon OBOR host countries.

External Threats. If OBOR creates an economic "bubble" that becomes pierced, OBOR will be proven to be an internal Weakness on China's domestic economy. Should that happen, OBOR will pose an external Threat to China, each OBOR host country may pose an external Threat to its neighbors, as OBOR host nations individually or collectively blame China and each other for their emerging economic woes. Some of the largest external Threats to China loom from its neighbors. DPRK appears to be bent on challenging the United States and Western Allies such as Japan and South Korea, conduct that could drag China into rapidly escalating warfare. 
Countries such as India and Japan, as well as ASEAN bloc member states are likely to respond negatively toward Chinese fortifications of international waterways. Chinese acquisition of ports along the Indian Ocean will be likely to antagonize India, much as OBOR will be likely to antagonize the Russian Federation once it becomes fully operational, and, as mentioned, if OBOR does become an economic "bubble" that will saddle China with an obligation to absorb the debt it has extended to OBOR host states that those nations will refuse to repay, and probably discontinue servicing, because the debt will seem to be, or even actually become, insurmountable.

\section{Conclusion}

Rising tensions along the Western Pacific rim can function as both obstacles and opportunities: obstacles to stronger East and West relations in the short term, opportunities for national actors in the neighborhood to come together in the longer term. Some tensions are unlikely to subside without intervention by Asian neighbors themselves alongside of Western partners, an example being North Korea and its erratic testing of missiles seemingly intended to make tensions rise irrationally. Western Allies including Japan and South Korea expect intervention from the United States, and the European Community, but unilateral action taken by the West without strong Asian support will be likely to increase rather than to decrease tensions. Despite rising tensions in Asia, some of them interfacing with each other, China's determination to construct its OBOR "dragon head" deep water cargo port at Piraeus, Greece, will alter the architecture of the European Community and its neighborhood for the better. In the ultimate analysis, China's OBOR is very risky across Eurasia, potentially lifesaving to Greece and a boost to growing prosperity in other countries of the CEEC block, particularly Poland. Because risks are abundant, trust is everything, and trust will be the Key Success Factor (KSF) if OBOR is to succeed. If all goes well and as China has planned, mutual trust among OBOR host nations themselves as well as between OBOR host nations, both individually and collectively, and China, fashioning an enormous external Opportunity for China and all the other participants. Tensions in Asia will be likely to wane, ultimately disappear, if OBOR is successful. In that case, OBOR will have facilitated a "quixotic encirclement" of Eurasia as a useful tool in Chinese foreign policy as envisioned by the senior author in Four Eagles and a Dragon (Jones 2015a). 


\section{References}

Alhadeff, I. 2015, "The War for the Railways and the Motorways of the New Silk Roads," Wordpress.com, https://iakal.wordpress.com/2015/09/22/the-war-for-the-railwaysand-the-motorways-of-the-new-silk-roads/.

Allison, G. 2017a, Destined for War: Can America and China Escape Thucydides's Trap?, Houghton Mifflin Company, Boston.

Allison, G. 2017b, "What Xi Jinping Wants," Defense One, http://www.defenseone.com/ ideas/2017/06/what-xi-jinping-wants/138309/.

Allison, G. 2017c, "China vs. America: Managing the Next Clash of Civilizations," Foreign Affairs, vol. 96, no. 5, https://www.foreignaffairs.com/articles/united-states/2017-08-15/china-vs-america.

Allison, G. \& Goldberg, A. 2017, "The Atlantic Exchange," The Atlantic, https://www. theatlantic.com/live/events/atlantic-exchange-graham-allison/2017/.

Annual Report to Congress: Military and Security Developments Involving the People's Republic of China 2016. Washington: U.S. Department of Defense, http://freebeacon. com/wp-content/uploads/2016/05/2016-China-Military-Power-Report_FINAL_forweb.pdf.

Annual Report to Congress: Military and Security Developments Involving the People's Republic of China 2017: A Report to Congress Pursuant to the National Defense Authorization Act for 2017. Office of the Secretary of Defense, Washington, https:// www.defense.gov/Portals/1/Documents/pubs/2017_China_Military_Power_Report. PDF ? source $=$ GovDelivery.

Asada, S. 2006, From Mahan to Pearl Harbor: The Imperial Japanese Navy and the United States. United States Naval Institute Press, Annapolis.

Bandow, D. 2016, "Will China Solve the North Korea Problem? The United States Should Develop a Diplomatic Strategy to Persuade Beijing to Help," Cato Institute Policy Paper No. 806, https://www.cato.org/publications/policy-analysis/will-china-solvenorth-korea-problem\#full.

Beech, E. 2017, "China Builds New Military Facilities on South China Sea Islands: Think Tank," Reuters, http://www.reuters.com/article/us-southchinasea-china-islands-idUSKBN19L02J? feedType $=$ RSS \&feedName $=$ worldNews \&utm_source $=$ feedburner\&utm_medium $=$ feed \&utm_campaign $=$ Feed $\% 3 \mathrm{~A}+$ Reuters $\%$ 2Fworld News $+\% 28$ Reuters + World + News\%29\&utm_content $=$ Yahoo + Search + Results.

"Beijing's South China Sea outposts nearly set for missile deployment: report" 2017, Agence France-Presse (AFP). June 30, http://www.ndtv.com/world-news/beijingssouth-china-sea-outposts-nearly-set-for-missile-deployment-report-1718711.

Bersjhidsky, L. 2017, "Negotiate with North Korea? A Russian Tried," Bloomberg, https:// www.bloomberg.com/view/articles/2017-09-08/negotiate-with-north-korea-a-russian-tried.

Blake, A. 2017, "Trump's menacing United Nations speech, annotated," The Washington Post, https://www.washingtonpost.com/news/the-fix/wp/2017/09/19/trumps-menacing-united-nations-speech-annotated/?utm_term $=.0 \mathrm{~b} 2 \mathrm{~b} 8 \mathrm{e} 88380 \mathrm{e}$.

Bray, B. 2017, "How America Is Losing The Battle For The South China Sea," The National Interest, http://nationalinterest.org/feature/how-america-losing-the-battle-thesouth-china-sea-22522.

Cai, P. 2017, "Why India distrusts China's One Belt One Road initiative," The Interpreter, Lowy Institute, https://www.lowyinstitute.org/the-interpreter/why-india-distrustschinas-one-belt-one-road-initiative. 
Carpenter, T. 2017a, “Trump's Strategy for Getting China to Pressure North Korea: All Sticks, No Carrots," Cato Institute, https://www.cato.org/blog/trumps-strategy-getting-china-pressure-north-korea-all-sticks-no-carrots.

Carpenter, T. 2017b, "Incentivizing China on N. Korea Requires Creative U.S. Diplomacy," China-U.S.Focus.com, http://www.chinausfocus.com/foreign-policy/incentivizing-china-on-n-korea-requires-creative-us-diplomacy.

Chandran, N. 2017, "Trump may turn to Vietnam for help on South China Sea,"CNBC. com, http:/www.cnbc.com/2017/05/31/trump-may-turn-to-vietnam-for-help-onsouth-china-sea.html?_source $=$ yahoo $\% 7$ Cfinance $\% 7$ Cheadline $\% 7$ Cheadline $\% 7 \mathrm{C}$ story\&par $=$ yahoo\&doc $=104500429 \& y p t r=y a h o o$.

Cheng, D. 2017, "Trump Signals New US Approach to China With Tough Actions," The Daily Signal, http://dailysignal.com/2017/05/26/trump-signals-new-us-approach-china-tough-actions/.

Cheever, Daniel S. 1984. "The Politics of the UN Convention on the Law of the Sea", Journal of International Affairs, Vol. 37, No. 2, 247-252. Winter. Retrieved from http:// www.jstor.org/stable/24356928

"China's Project of the Century," German-Foreign-Policy.com. 15 May 2017. https://www. german-foreign-policy.com/en/news/detail/7294/.

"China sets its sights on dominating sunrise industries: But its record of industrial-policy successes is patchy," The Economist, https://www.economist.com/news/finance-andeconomics/21729442-its-record-industrial-policy-successes-patchy-china-sets-itssights.

Clover, C. \& Hornby, L. 2017, "China's Great Game: Road to a New Empire," Financial Times, https://www.ft.com/content/6e098274-587a-11e5-a28b-50226830d644.

"Cosco Shipping Ports' Profit Down as Volumes Rise," World Maritime News. 25 April 2017. https://worldmaritimenews.com/archives/218523/cosco-shipping-ports-profitdown-as-volumes-ris"China's Proe/.

"The FDI Report 2017," FDI Intelligence, http://forms.fdiintelligence.com/report2017/ ?ref = solusemail\&utm_campaign $=$ The $+\mathrm{fDi}+$ Report $+2017+-+$ out + now \&utm source=emailCampaign \&utm_medium =email\&utm_content.

Gladstone, R. \& Sangar, D. 2017, "North Korea Says It Has the Right to Shoot Down U.S. Warplanes," The New York Times, https://www.nytimes.com/2017/09/25/world/asia/ trump-north-korea.html? clickSource $=$ story-heading \& smtyp $=$ cur.

Grant, S. 2017, "Water Wars: China, China Everywhere, Under the Sea and In the Air," Lawfare, https://www.lawfareblog.com/water-wars-china-china-everywhere-undersea-and-airl.

Griffiths, J. 2017, "Beijing Plans Underwater Observation System in South China Sea," CNN.com, http://edition.cnn.com/2017/05/29/asia/south-china-sea-underwater-observation-system/index.html.

"Harvard's Allison Says Trump's Fearful of a Growing China," Bloomberg, https://www. bloomberg.com/news/videos/2017-05-30/harvard-s-allison-trump-fearful-of-a-growing-china-video.

He, Y. 2017, "OBOR: Innovation for Global Governance," China US Focus. 10 May, https://www.chinausfocus.com/videos/obor-innovation-for-global-governance

"The Hidden Motives of the Chinese Silk Road" 2017, Yale Global, http://oilprice.com/ Energy/Energy-General/The-Hidden-Motives-Of-The-Chinese-Silk-Road.html.

Horowitz, J. \& Alderman, L. 2017, "Chastised by E.U., a Resentful Greece Embraces China's Cash and Interests, The New York Times. 26 Aug., https://www.nytimes. com/2017/08/26/world/europe/greece-china-piraeus-alexis-tsipras.html. 
Jennings, R. 2015, "Obstacles at Bay, Beijing Steps up Control Over Disputed South China Sea," Voice of America (VOA) News, https://www.voanews.com/a/obstacles-at-baybeijing-steps-up-control-over-disputed-south-china-sea/3906068.html.

Jones, D. 2013, "Avoiding Foreign Deceptive Investment: Lawfully and Legitimately Structuring Asian Foreign Direct Investment (FDI) in Central and Eastern Europe," ASM International Journal of Ongoing Research in Management and IT," Issue 1, INCON13- Finance-032, pp. 1-12.

Jones, D. 2015a, Four Eagles and a Dragon: Successes and Failures of Quixotic Encirclement Strategies in Foreign Policy, An Analysis. London and New Delhi: Bloomsbury, Plc.

Jones, D. 2015b, "Hybrid Conflict and Encirclement: Reconfiguration of Eastern Europe by NATO, Trade Barriers, and a Chinese Solution for Greece," Journal of International Relations and Diplomacy, vol. 3, No. 8, pp. 497-510, http://www.davidpublisher. org/Public/uploads/Contribute/55ebfd364c909.pdf.

Jones, D. \& Liu, H. 2017, "Management of Chinese Foreign Direct Investment: 'One Belt, One Road' Across Eurasia to Africa and Europe Amidst Maritime Tensions in the South China Sea Region," Journal of International Relations et) Diplomacy, vol. 5, No. 8, pp. 486-500, http://www.davidpublisher.org/Public/uploads/Contribute/59cf3c2bbc994.pdf.

Keefe, J. 2018, "COSCO Shipping's H1 Profit Falls 98 pct," Maritime Logistics Professional. 30 Aug., https://www.maritimeprofessional.com/news/cosco-shipping-profit-falls-321009.

Khalilzad, Z., Orletsky, D., Pollack, J., Pollpeter, K., Rabasa, A., Shlapak, D., Shulsky, A., \& Tellis, A. 2001, The United States and Asia: Toward a New U.S. Strategy and Force Posture. RAND Corporation, Santa Monica, CA, https://www.rand.org/pubs/monograph_reports/MR1315.html.

Krishnamoorthy, N. 2017a, "China deployed nuclear-capable missiles to ground targets in US west coast, Pentagon says," International Business Times, http://www.ibtimes. co.uk/china-deployed-nuclear-capable-missiles-ground-targets-us-west-coast-pentagon-says-1625125.

Krishnamoorthy, N. 2017b, "US navy deployed B-1B supersonic bombers and guided-missile destroyer to South China Sea," International Business Times, http://www. ibtimes.co.uk/us-navy-deployed-b-1b-supersonic-bombers-guided-missile-destroyersouth-china-sea-1625484.

$\mathrm{Ku}$, J. 2017, "Why the U.S. Can't Take Sides in South China Sea Sovereignty Disputes, Even Against China," Lawfare, https://lawfareblog.com/why-us-cant-take-sidessouth-china-sea-sovereignty-disputes-even-against-china.

"Laos: On the Borders of the Empire," Al Jazeera News, 2017, http://www.aljazeera.com/ programmes/peopleandpower/2017/05/laos-borders-empire-170522105221541. html.

Liu, S. 2017, "The record of the Regular Express," Chinese Ministry of National Defense, Beijing, http://www.mod.gov.cn/shouye/2017-05/25/content_4781393_2.htm.

Lu, Hua. 2017, "How the Belt and Road Project Fills a Global Governance Vacuum," Sixth Tone.

12 Nov. http://www.sixthtone.com/news/1001159/how-the-belt-and-road-project-fills-aglobal-governance-vacuum.

Mahan, A.T. 1890, The Influence of Sea Power Upon History, Little Brown \& Co., Boston.

Mangi, F. 2016, "China's New Silk Road Hinges on a Small Pakistan Port," Bloomberg, https://www.bloomberg.com/news/articles/2016-09-29/china-s-new-silk-road-hingeson-a-small-pakistan-port. 
Martin, P. \& Chen, S. 2017, "North Korea Sanctions Claim Another Victim: China's Rust Belt," Bloomberg, http://www.msn.com/en-us/money/markets/north-korea-sanctionsclaim-another-victim-chinas-rust-belt/ar-AAsh5mx?li=AA4Zjn\&ocid=spartandhp.

Mollman, S. 2017, "North Korea Is Helping China in the South China Sea-Whether It Knows It or Not," Defense One, http://www.defenseone.com/threats/2017/05/northkorea-helping-china-south-china-seawhether-it-knows-it-or-not/138245/.

O'Connor, T. 2017, "U.S. Military Report Driven by 'Cold War Thinking'," Newsweek, http:// www.newsweek.com/china-dispute-military-power-us-defense-cold-war-623860.

Phillips, T. 2017, "China's Xi lays out \$900bn Silk Road vision amid claims of empire-building," The Guardian, https://www.theguardian.com/world/2017/may/14/china-xi-silk-road-vision-belt-and-road-claims-empire-building.

Pickrell, R. 2017, "New Pentagon Report Finally Drags China's Secret Sea Weapon Out Of The Shadows," The Daily Caller News Foundation, http://dailycaller.com/2017/06/07/ new-pentagon-report-finally-drags-chinas-secret-sea-weapon-out-of-the-shadows/.

Platt Amendment to the Treaty between the United States and the Republic of Cuba, 22 May 1903, https://www.ourdocuments.gov/doc.php?flash=true\&doc $=55$

"'Quad' of democracies vs. China: a new clash of civilizations?" National Endowment for Democracy, Democracy Digest. 20 November 2017, https://www.demdigest.org/ quad-democracies-vs-china-new-clash-civilizations/\#respond.

Ross, E. 2017, "South China Sea: Chinese Military Planes Raise New Concerns Of Conflict in Asia," Newsweek, http://www.newsweek.com/south-china-sea-chinese-military-planes- raise-new-concerns-conflict-asia-628479.

Sanwal, Mukul 2016, "China's One-Road-One Belt Initiative: A New Model of Global Governance," Indian Institute for Defence Studies and Analysis, New Delhi. 29 Sep. https://idsa.in/idsacomments/china-one-road-one-belt-initiative_msanwal_290916.

Savranskaya, S. \& Blanton, T., (eds.) 2006, "The Reykjavik File: Previously Secret Documents from U.S. and Soviet Archives on the 1986 Reagan-Gorbachev Summit," The National Security Archive Electronic Briefing Book No. 203, George Washington University, Washington DC, http://nsarchive2.gwu.edu//NSAEBB/NSAEBB203/index.htm.

Soesanto, S. 2017, "Let U.S. Deterrence Fail on the Korean Peninsula," The National Interest, http://nationalinterest.org/feature/let-us-deterrence-fail-the-korean-peninsula-22441.

The South China Sea Arbitration (The Republic of Philippines v. The People's Republic of China) No. 2013-19 decided 12 July 2016. The formal caption of this case is An Arbitration before an arbitral tribunal constituted under Annex VII to the 1982 United Nations Convention on Law of the Sea between the Republic of the Philippines and the People's Republic of China, https://pcacases.com/web/view/7.

"South China Sea: Chinese Military Unveils First of 18 'New Generation' Warships," Asia Maritime Reviews, http://asiamaritime.net/south-china-sea-chinese-militaryunveils-first-of-18-new-generation-warships/.

Statistics Times 2015, "United States vs. China GDP," http://statisticstimes.com/economy/united-states-vs-china-gdp.php.

Sumida, J.T. 2006, "Geography, technology, and British naval strategy in the dreadnought era," United States Naval War College Review, vol. 59, No. 3, pp. 89-103.

Tanoos, J. 2014, "Post-Cold War State Industrialization as a Means of Economic Growth in East Asia versus Eastern Europe," European Scientific Journal, Special Edition, vol. 1, Sep., http://eujournal.org/index.php/esj/article/viewFile/4113/3946.

Toussaint, E. 2011, "Core vs. Periphery in the EU," Committee for the Abolition of Illegitimate Debt (CADTM), http://www.cadtm.org/Core-vs-Periphery-in-the-EU. 
$38 \vdots$ David A. Jones, Hanzhen Liu

The United States and China in Power Transition 2017, Progressive Management Publications, Cleveland $\mathrm{OH}$, https://www.amazon.com/United-States-China-Power-Transition/dp/1521319685? SubscriptionId=AKIAJTPUO22B732H2OVA\&tag=ndkglobal-20 \&linkCode $=x m 2 \&$ camp $=2025 \&$ creative $=165953 \&$ creativeASIN $=1521319685$ \#reader 1521319685.

Villamor, F. 2017, "Duterte Says Xi Warned Philippines of War Over South China Sea," The New York Times, https://www.nytimes.com/2017/05/19/world/asia/philippines-south-china-sea-duterte-war.html?_r $=0$.

Woo, R. 2017, "China 'strongly dissatisfied' with G7 statement on East, South China Seas," Reuters, http://www.reuters.com/article/us-g7-summit-southchinasea-idUSKBN18O01H $=$.

Xin, W. 2017a, 《“一带一路” 合作倡议没有军事和地缘战略意图, 中国不谋求地区事务 主导权, 不谋求势力范围, 不会干涉别国内政。》 [“Ministry of Defense: 'along the way' no military cooperation initiative and geo-strategic intent"], People's Republic of China Ministry of Defense, http://www.china.com.cn/military/2017-05/25/content_40891444.htm.

Xin, W. 2017b, 《国防部: 中国不存在 “隐形军费》[“The Ministry of Defense: No invisible military expense in China"], People's Republic of China Ministry of Defense, http://www.china.com.cn/military/2017-05/25/content_40891628.htm.

Yang, H. \& Park, J. 2017, "'Shocked' South Korea Leader Moon orders probe into U.S. THAAD additions," Reuters, http://www.reuters.com/article/us-northkorea-missiles-south-thaad-idUSKBN18Q0I3. 